\title{
Smoking tends to decrease glutathione and increase malondialdehyde levels in medical students
}

\author{
Safyudin* and Subandrate*
}

\begin{abstract}
*Department of Biochemistry and Medicinal Chemistry,

Faculty of Medicine,

Sriwijaya University

Correspondence :

Subandrate

Department of Biochemistry and

Medicinal Chemistry,

\section{BACKGROUND}

Smoking is the act of introducing toxic substances into the body. Cigarette smoke contains chemicals that may cause several disorders, including cardiovascular disease, cancer, and chronic obstructive pulmonary disease. Toxic substances in cigarette smoke have the potential to increase free radicals, malondialdehyde (MDA) levels and to decrease endogenous antioxidant (glutathione/GSH) levels. This study aims to determine the relationship of smoking with plasma GSH and MDA levels in medical students.
\end{abstract}

Faculty of Medicine,

Sriwijaya University

Jalan Dr. M. Ali

Komplek RSMH Km 3,5

Palembang 30126

Phone and fax: $+62711-373438$

Email: saratebasyam@yahoo.com

Univ Med 2016;35:89-95

DOI: 10.18051/UnivMed.2016.v35.89-95 pISSN: 1907-3062 / eISSN: 2407-2230

This open access article is distributed under a Creative Commons Attribution-Non Commercial-Share Alike 4.0 International License

\section{METHODS}

This study was analytical observational with cross-sectional approach. The study was conducted from April to December 2015. The subjects in this study were medical students, consisting of 20 smokers and 20 nonsmokers. Plasma GSH and MDA levels were determined biochemically using Sigma GSH Assay Kit and Sigma MDA Assay Kit. Data was analyzed using the independent $t$ test.

\section{RESULTS}

The results showed that there was no significant difference between mean GSH in smokers $(1.74 \pm 0.91 \mu \mathrm{mol} / \mathrm{L})$ and nonsmokers $(2.42 \pm 1.19$ $\mu \mathrm{mol} / \mathrm{L})(\mathrm{p}=0.441)$. Mean smokers MDA level of $2.06 \pm 1.39 \mathrm{nmol} / \mu \mathrm{L}$ was not significantly different compared with mean nonsmokers MDA level $(1.32 \pm 0.90 \mathrm{nmol} / \mu \mathrm{L})(\mathrm{p}=0.092)$.

\section{CONCLUSIONS}

Smoking tends to decrease plasma GSH levels and increase plasma MDA levels in medical students. Smoking history could be evidence of oxidative stress and an impaired oxidant defense system. In particular, young smokers should quit promptly before health problems arise, so as to have the optimal benefits of cessation.

Keyword: Free radicals, GSH, MDA, smoking, medical students 


\section{INTRODUCTION}

Smoking is the act of introducing toxic substances into the body. Cigarette smoke inhaled by a smoker contains hazardous compounds that are detrimental to health. Smoking is at present still a threat to global public health, particularly in developing countries such as Indonesia. Cigarette consumption in Indonesia is steadily on the increase. ${ }^{(1)}$ In 2007, the number of smokers in Indonesia was $34.2 \%$ and in 2013 it became $36.2 \%$. $^{(1)}$ The WHO even predicts that the number of smokers in Indonesia will increase up to $45 \%$ in the year 2025, if the Indonesian government does not issue a strict cigarette policy. ${ }^{(2)}$ Which is also astounding is that Indonesia ranks fifth in cigarette consumption in the world after China, the US, Russia and Japan. ${ }^{(2)}$ The results of a study by the Ministry of Health of the Republic of Indonesia for the year 2011 showed that around $31 \%$ of smokers in Indonesia are non-university students and almost $75 \%$ of private university students in Sumatra are smokers. ${ }^{(1,2)}$ In the US, the age range of 18-24 years has the highest prevalence of smokers. ${ }^{(1)}$

It is known that cigarette smoke contains toxic compounds such as tar, nicotine, lead, and carbon monoxide that can adversely affect health. ${ }^{(3)}$ The habit of smoking increases blood lead concentrations. ${ }^{(4)}$ In addition, smoking in the long run can cause disturbed lung function and can increase chronic obstructive pulmonary disease and skeletal muscle dysfunction. ${ }^{(5,6)}$ The results of a study on experimental animals showed that cigarette smoke increased pulmonary alveolar cell death. ${ }^{(7)}$ The gaseous and particulate components of cigarette smoke are potential inducers of free radicals. ${ }^{(3,8)}$ The results of a study showed the presence of free radicals in periodontal tissues of smokers. ${ }^{(8)}$ The results of another study in rats showed that exposure to cigarettes, whether electronic or conventional, can disturb rat spermatogenesis through an increase in free radicals. ${ }^{(9)}$

Free radicals are extremely reactive compounds and thus easily react with other compounds such as lipids, DNA and proteins. Free radical oxidation causes tissue or organ damage so as to cause illness. ${ }^{(10,11)}$ Cigarettes are suspected of being one of the sources of increases in free radicals in the body and are associated with various chronic pulmonary and cardiovascular diseases. The increase in free radicals in the body causes oxidative stress. ${ }^{(3,8,9)}$

Oxidative stress is an increase in oxidants (free radicals) and/or decrease in antioxidants in the body. One of the markers that is frequently used to evaluate oxidative stress is the malondialdehyde (MDA) concentration. MDA is the end product of lipid peroxidation by free radicals. ${ }^{(10,11)}$ An increase in MDA concentration indicates an increase in free radicals in the body. Apart from MDA, another marker that is frequently used to evaluate oxidative stress is glutathione (GSH). GSH is one of the endogenous antioxidants that play a role in cleaving free radicals. In conditions of oxidative stress, the GSH concentration decreases. ${ }^{(3,9)}$ In addition to MDA and GSH, other markers that can be used to evaluate oxidative stress are superoxide dismutase (SOD), glutathione peroxidase (GPx), catalase and carbonyl compounds. ${ }^{(9,10)}$

Several studies have shown that smoking is associated with increased aging, cell damage, and disease through the mechanism of oxidative stress. In smokers, there is a tendency for an increase in free radicals and a decrease in antioxidants to occur. ${ }^{(7,10,11)}$ However, these studies used a considerably broad age range, from young to old.

The study by Omotoso et al. ${ }^{(12)}$ in rats showed that exposure to cigarette smoke decreased plasma malondialdehyde concentrations. Similarly, the study of Koubaa et al. ${ }^{(13)}$ reported that MDA concentrations were lower in smokers than in nonsmokers. In contrast, a study on thirty healthy adult subjects (15 smokers and 15 nonsmokers) showed no significant changes in GSH and MDA concentrations of smokers. ${ }^{(14)}$

In view of the large numbers of smokers in Indonesia particularly among university students and the differing results of previous studies, it 
was felt necessary to conduct another study on the association of smoking with MDA and GSH concentrations in smokers.

\section{METHODS}

\section{Research design}

This was an analytical observational study with cross-sectional approach that was conducted from April until December 2015 in the medical study program of the Faculty of Medicine, Sriwijaya University, Palembang, South Sumatra.

\section{Study subjects}

The study sample comprised all smoking students aged 18-22 years in the medical study program of the Faculty of Medicine, Sriwijaya University, who met the inclusion criterion and did not meet the exclusion criteria. The inclusion criterion was healthy males, while the exclusion criteria were students who were ill or had a history of a metabolic disorder, such as diabetes mellitus and cardiac and renal disorders. The subjects to be included in the sample were recruited by identifying all smokers and selecting the subjects according to the inclusion criterion. The sample size was determined using Slovin's formula, ${ }^{(15)}$ namely $\mathrm{n}=\mathrm{N} /\left(1+\mathrm{N} \times \mathrm{e}^{2}\right)$, where $\mathrm{N}$ is the population size, and $\mathrm{e}$ is the margin of error. Applying a 5\% error margin in Slovin's formula, the recommended minimum sample size was 40 . The sample size that was obtained in this study was 20 smoking students and 20 nonsmoking students. The study subjects were selected using simple random sampling by lot after those involved agreed to participate in the study and had been given an explanation of the benefits and discomforts of the participation in this study. Their willingness to participate in the study was recorded by signing informed consent.

\section{Data collection}

Collection of the sample data was performed by interviews using a questionnaire, which included the subjects' identity (using initials only), age, gender, duration of smoking, and number of cigarettes per day.

\section{Laboratory analysis}

A blood sample of $2 \mathrm{ml}$ was drawn at 07.30 AM West Indonesian Time from the left median cubital vein of each (nonfasting) study subject using a 3-mL syringe. The blood samples were then centrifuged at $5000 \mathrm{rpm}$ for 2 minutes to obtain plasma, which was then stored at $-20^{\circ} \mathrm{C}$, before being used for measurement of GSH and MDA concentrations.

The plasma GSH and MDA concentrations were determined in the Biochemistry Laboratory and the Molecular Biology Laboratory, Faculty of Medicine, Sriwijaya University. The plasma GSH and MDA concentrations were measured biochemically using the Sigma GSH and MDA assay kits, respectively.

Determination of plasma GSH concentrations was done biochemically using the Sigma GSH assay kit. A volume of $200 \mu \mathrm{l}$ plasma was deproteinized with $200 \mu \mathrm{l}$ of $5 \% 5$ sulfosalicylic acid (SSA). The mixture was then vortexed and left standing for 10 minutes at 2$8^{\circ} \mathrm{C}$. Subsequently the mixture was centrifuged at $10,000 \mathrm{~g}$ for 10 minutes to remove the precipitated protein. Then $10 \mu \mathrm{l}$ of the supernatant was taken and mixed with $150 \mu \mathrm{l}$ working mixture in each well of a 96-well plate. The mixture was incubated for 5 minutes at room temperature, then $50 \mu \mathrm{l}$ of NADPH solution was added and the absorbance was measured using a spectrophotometer at a wavelength of $412 \mathrm{~nm}$. The GSH concentration was then determined on the GSH standard curve in units of $\mu \mathrm{mol} / \mathrm{L}$.

Determination of plasma MDA concentrations was done biochemically using the Sigma MDA assay kit. A volume of $10 \mu \mathrm{l}$ plasma was mixed with $500 \mu \mathrm{l}$ of $42 \mathrm{mM} \mathrm{H}_{2} \mathrm{SO}_{4}$ and 125 $\mu l$ phosphotungstic acid in a microcentrifuge tube. The mixture was vortexed and incubated at room temperature for 5 minutes, then centrifuged at $3,000 \mathrm{~g}$ for 3 minutes. The precipitate was 
Table 1. Distribution of characteristics of smokers and nonsmokers

\begin{tabular}{lccc}
\hline \multicolumn{1}{c}{ Variable } & Smokers (n=20) & Nonsmokers (n=20) & p \\
\hline Age (years) & $21.00 \pm 1.07$ & $20.00 \pm 1.41$ & 0.163 \\
Duration of sm oking (years) & $5.00 \pm 2.00$ & - & \\
Num ber of cigarettes per day & $9.00 \pm 4.36$ & - & \\
\hline
\end{tabular}

collected and resuspended in a 3,5-Di-tert-4butylhydroxytoluene (BHT)-distilled water solution and adjusted to a volume of $200 \mu \mathrm{l}$ with water. Afterwards, $600 \mu \mathrm{l}$ of thiobarbituric acid (TBA) solution was added to the suspension and incubated at $95^{\circ} \mathrm{C}$ for 60 minutes. The mixture was then cooled in an ice bath for 10 minutes. The $200 \mu \mathrm{l}$ mixture was placed into a 96-well plate and the absorbance read using a spectrophotometer at $532 \mathrm{~nm}$ wave length. MDA concentrations were then determined using the MDA standard curve in units of $n \mathrm{~mol} / \mu \mathrm{L}$.

\section{Statistical analysis}

The data were processed and analyzed using SPSS version 16 . The statistical analysis used was the independent t-test at a level of significance of 0.05 .

\section{Ethical clearance}

The study was conducted after obtaining ethical clearance from the Unit for Bioethics and Humaniora, Mohammad Hoesin Central General Hospital and the Faculty of Medicine, Sriwijaya University, Palembang, under No. 152/ kepkrsmhfkunsri/2015.

\section{RESULTS}

Smoking study subjects had a mean age of $21.0 \pm 1.07$ years, mean duration of smoking of $5.0 \pm 2.0$ years, and mean number of cigarettes smoked per day of $9.0 \pm 4.36$ cigarettes. The subject characteristics can be seen in Table 1 .

On determination of plasma GSH concentration it was found that mean GSH concentrations of the smoking and nonsmoking study subjects were $1.74 \pm 0.91 \mu \mathrm{mol} / \mathrm{L}$ and 2.42 $\pm 1.19 \mu \mathrm{mol} / \mathrm{L}$, respectively (Table 2 ). Thus plasma GSH concentration in smokers was lower than in nonsmokers, but the difference was statistically not significant $(\mathrm{p}=0.441)$. This means that smoking did not significantly decrease GSH concentration.

On determination of plasma MDA concentration it was found that mean MDA concentration of the smoking study subjects was $2.06 \pm 1.39 \mathrm{nmol} / \mu \mathrm{L}$ and that of the nonsmoking study subjects $1.3 \pm 0.90 \mathrm{nmol} / \mu \mathrm{L}$. Therefore, the plasma MDA concentration in smokers was higher than in nonsmokers, but the difference was statistically not significant ( $\mathrm{p}=0.092)$ (Table 2$)$. This indicates that smoking did not significantly increase plasma MDA concentration.

The correlation of duration of smoking and number of cigarettes per day with GSH concentration resulted in $\mathrm{r}=0.108(\mathrm{p}=0.650)$ and $\mathrm{r}=0.316(\mathrm{p}=0.175)$, respectively, which were statistically not significant. The correlation of duration of smoking and number of cigarettes per day with MDA concentrations also resulted in $\mathrm{r}=-0.132(\mathrm{p}=0.579)$ and $\mathrm{r}=-0.117(\mathrm{p}=0.624)$, which again were statistically not significant (Table 3).

Table 2. Differences in GSH and MDA concentrations between smokers and nonsmokers

\begin{tabular}{lccc}
\hline \multicolumn{1}{c}{ Variable } & Smokers $(\mathbf{n}=\mathbf{2 0})$ & Nonsmokers $(\mathbf{n}=\mathbf{2 0})$ & $\mathbf{p}$ \\
\hline $\mathrm{GSH}(\mu \mathrm{mol} / \mathrm{L})$ & $1.74 \pm 0.91$ & $2.42 \pm 1.19$ & 0.441 \\
$\mathrm{MDA}(\mathrm{nmol} / \mu \mathrm{L})$ & $2.06 \pm 1.39$ & $1.3 \pm 0.90$ & 0.092 \\
\hline
\end{tabular}

$\mathrm{GSH}=$ glutathione; $\mathrm{MDA}=$ malondialdehyde; $*$ Independent $\mathrm{t}$-test ; significant at $\mathrm{p}<0.05$ 
Table 3. Correlation of duration of smoking and number of cigarettes per day with GSH and MDA concentrations

\begin{tabular}{lcccc}
\hline & \multicolumn{2}{c}{ GSH concentration } & \multicolumn{2}{c}{ MDA concentration } \\
\cline { 2 - 5 } & $\mathbf{r}$ & $\mathbf{p}$ & $\mathbf{r}$ & $\mathbf{p}$ \\
\hline Duration of an oking & 0.108 & 0.650 & -0.132 & 0.579 \\
Number of cigarettes per day & 0.316 & 0.175 & -0.117 & 0.624 \\
\hline
\end{tabular}

$\mathrm{GSH}=$ glutathione; $\mathrm{MDA}=$ malondialdehyde; $\mathrm{r}=$ Pearson correlation coefficient; significant at $\mathrm{p}<0.05$

\section{DISCUSSION}

The smokers in this study were 18-22 years of age, with mean duration of smoking of 5 years. With a view to the mean duration of smoking, it may be estimated that the age of the study subjects when they started smoking was 13-17 years, i.e. when they were adolescents (in junior or senior high school). At such an age, social influence, selfactualization, labile personality, and high level of curiosity, are the causes that these adolescents start smoking. The results of this study was comparable to those of the studies conducted by Reimondos et al. ${ }^{(16)}$ and Subandrate et al. ${ }^{(17)}$ who found that the age of smoking initiation was around 13-15 years. The smokers in our study were habitual or routine smokers, with mean daily consumption of around 9 cigarettes. This is in agreement with previous studies reporting that on average the smokers consumed 10-11 cigarettes or one pack per day. ${ }^{(1,16)}$

Smoking is the act of introducing toxic substances into the body. When smoking, more than 2000 compounds enter the lungs in gaseous or particulate form. These toxic substances in the cigarette smoke, such as tar, nicotine, lead, carbon monoxide, nitrogen monoxide, benzopyrene, and nitrosamines, will subsequently be metabolized in the liver to yield oxidants or free radicals. ${ }^{(14,18)}$ Long-term and continual smoking leads to accumulation of these toxic substances in the body, so that there is an increase in free radicals, such as hydroxyl and superoxide radicals. The increase in free radicals causes an increase in oxidant markers such as MDA and a decrease in antioxidant markers such as GSH, glutathione peroxidase, catalase, and superoxide dismutase. ${ }^{(10,19)}$
In the present study, mean GSH concentration in smokers was lower than that in nonsmokers, but the difference was statistically not significant. Corresponding results were found in the study conducted by Abdul-Rasheed and Al-Rubayee, showing nonsignificant decreases in glutathione concentrations in smokers as compared with those of nonsmokers. ${ }^{(20)}$ However, different results were found in another study, where GSH concentrations were lower in smokers than in nonsmokers. ${ }^{(21)}$ This may have been caused by an increase in free radicals such as hydroxyl radicals, hydrogen peroxide, and superoxide anions, resulting from the accumulation of cigarette smoke oxidants. ${ }^{(10,11,18)}$ The increase in free radicals triggers the activity of endogenous antioxidants such as GSH, so as to reduce their plasma concentrations. GSH is a tripeptide with sulfhydryl groups, thus being capable of cleaving free radicals. GSH can quench free radicals directly or cleave hydroxyl radicals and superoxide anions by acting as cofactor of glutathione peroxidase, glutathione transhydrogenase and superoxide dismutase..$^{(10,11)}$ The results of our study also showed that mean MDA concentration in smokers was higher than in nonsmokers, but the difference was statistically not significant. Similar nonsignificant results were shown in the study conducted by Erguder et al. ${ }^{(22)}$ who found that serum MDA concentration was not significantly different between smokers and nonsmokers. In contrast, different results were shown in a study involving 22-25 year-old students in India, in that there was a significant increase in serum MDA concentration in smokers as compared with that of nonsmokers. ${ }^{(21)}$ This may have been possible because longterm and frequent 
cigarette exposure leads to accumulation of toxic substances and superoxide radicals, so as to induce oxidative stress. MDA is the end result of a chain of lipid peroxidation reactions by free radicals. Increases in MDA concentrations indicate that the cells undergo oxidative stress. ${ }^{(10,11)}$

A limitation of this study was that it did not perform an analysis on or exclusion of other factors that affect plasma antioxidant and oxidant concentration, such consumption of certain drugs, antioxidant supplements, a diet high in fruits and vegetables, and physical activity. The cross-sectional design that was used in this study does not allow it to explain any cause-and-effect relationship of smoking with GSH and MDA concentrations. Therefore, further studies need to be conducted of cohort or case-control design that can include an analysis of all these factors.

The body has the capacity to overcome free radicals, originating from within or from outside the body. In this study exposure to exogenous oxidants in the form of cigarette smoke did not have a significant impact on the increase in free radicals and reduction in endogenous antioxidants. This signifies that in healthy young adults, the impact of exogenous oxidant exposure can still be overcome.

\section{CONCLUSIONS}

Smoking tends to decrease plasma GSH concentration and increase plasma MDA concentration in medical students. Smokers are more susceptible to oxidant stress as a consequence of insufficient antioxidant potential and greater oxidative burden. In particular, young smokers should quit promptly before health problems arise, so as to have the optimal benefits of cessation.

\section{CONFLICT OF INTEREST}

There was no conflict of interest in this study.

\section{ACKNOWLEDGEMENT}

Thanks are due to Ahmad Wirawan and the chairman of the class of 2012-2015 of the medical study program of the Faculty of Medicine, Sriwijaya University, who assisted with sample recruitment.

\section{REFERENCES}

1. World Health Organization. WHO global report on trends in prevalence of tobacco smoking, 2015. Geneva: World Health Organisation; 2015.

2. Departemen Kesehatan RI. Riset kesehatan dasar tahun 2013. Jakarta: Badan Penelitian dan Pengembangan Departemen Kesehatan Republik Indonesia, 2013.

3. Tirtosastro S, Murdiyati AS. Kandungan kimia tembakau dan rokok. Buletin Tanaman Tembakau 2010;2:33-43.

4. Nurbaya F, Wijayanti Y. Faktor risiko yang berhubungan dengan kadar timah hitam dalam darah. Kemas 2010:6:51-6.

5. Nurjanah, Kresnawati L, Mufid A. Gangguan fungsi paru dan kadar nikotin pada urin karyawan yang terpapar asap rokok orang lain. Kemas 2014;10:43-52.

6. Degens H, Gayan-Ramirez G, van Hees HWH. Smoking-induced skeletal muscle dysfunction from evidence to mechanisms. Am J Respir Crit Care Med 2015;191:620-5.

7. Atik N, Avriyanti E, Iwan ARJ, et al. Pengaruh lidah buaya (Aloe vera $L$.) pada paru-paru tikus yang diinduksi asap rokok. Majalah Kedokteran Bandung 2012;44:159-64.

8. Reejamol MK, Swaminathan M. Estimation of lipid peroxides and antioxidants in smokers and non-smokers with periodontitis. King Saudi Univ J Dent Sci 2013;4:53-6.

9. Hybertson BM, Gao B, Bose SK, et al. Oxidative stress in health and disease: the therapeutic potential of Nrf2 activation. Mol Aspects Med 2011;32:234-46.

10. Pasupathi P, Saravanan G, Farook J. Oxidative stress bio markers and antioxidant status in cigarette smokers compared to nonsmokers. J Pharm Sci Res 2009;1:55-62.

11. Donohue JF. Ageing, smoking and oxidative stress. Thorax 2006;61:461-2.

12. Omotoso GO, Kadir RE, AlabiI JT, et al. Exposure to cigarette smoke altered the cytoarchitecture and anti-oxidant activity of the frontal cortex in Wistar rats. Int $\mathrm{J}$ Biol Chem Sci 2013;7:1595-60. 
13. Koubaa A, Triki M, Trabelsi H, et al. The effect of a 12-week moderate intensity interval training program on the antioxidant defense capability and lipid profile in men smoking cigarettes or hookah: a cohort study. Sci World J 2015; 2015: 1-9.

14. Chávez J, Cano C, Souki A, et al. Effect of cigarette smoking on the oxidation/antioxidation balance in healthy subjects. Rev Latinoam Hipertens 2006;1:33-7.

15. Tejada JJ, Punzalan JRB. On the misuse of Slovin's formula. Philippine Statistician 2012; 61:129-36.

16. Subandrate, Safyudin, Arifin M, et al. Kadar superoksida dismutase mahasiswa perokok di Program Studi Pendidikan Dokter Universitas Sriwijaya. Jurnal Kedokteran Yarsi 2015;23:7682.

17. Reimondos A, Utomo ID, McDonald P, et al. Smoking and young adults in Indonesia. Australian Demographic and Social Research Institute, The Australian National University; 2012.
18. Barreiro E, Peinado VI, Galdiz JB, et al. Cigarette smoke-induced oxidative stress. Am J Resp Crit Care Med 2010;182:477-88.

19. Rajalakshmi G, Sudha G. Reduced plasma antioxidant level in smoking asthmatic. Int Res J Pharm 2013;3:142-4.

20. Abdul-Rashees OF, Al-Rubayee WT. Effects of cigarette smoking on lipid peroxidation and antioxidant status in Iraqi men at Baghdad city. Int J Basic Appl Sci 2013;2:47-50.

21. Mahapatra SK, Das S, Dey SK, et al. Smoking induced oxidative stress in serum and neutrophil of the university students. Al Ameen J Med Sci 2008;1:20-31.

22. Erguder IB, Ucar A, Ariturk I, et al. The effects of cigarette smoking on serum oxidant status, and cholesterol, homocysteine, folic acid, copper, and zinc levels in university students. Turk J Med Sci 2009;39:513-7. 